\title{
Study on Assessment of Outcomes of Education
}

\author{
G Aruna ${ }^{1}$, N Sudharsan ${ }^{2}$ \\ ${ }^{1}$ Department of Civil Engineering, CMR Institute of Technology, Hyderabad, India \\ ${ }^{2}$ Department of Civil Engineering, Vidya Jyothi Institute of Technology, Hyderabad, India \\ 1aarunasree@gmail.com \\ nksudhar@yahoo.co.in
}

\begin{abstract}
This paper describes the process for assessment of Course Outcomes (COs), Program and Program Specific Outcomes (POs \& PSOs). Direct and indirect method was used to assess the COs, POs and PSOs. In the direct method, continuous internal evaluation test, assignment, seminar, end semester examination as well as in the indirect method, number of surveys were carried out to assess the outcomes. Threshold approach was followed for assessing the attainment. Based on the attainment, existing gap can be identified and filled by improving the curriculum, teach learning process and skills of the graduate.
\end{abstract}

Keywords: Assessment, attainment, course outcomes, program outcomes, program-specific outcomes.

\section{Introduction}

Nowadays all the educational institutions are focused on Outcome Based Education (OBE). National Board of Accreditation (NBA), India is the permanent signatory member of the Washington Accord and framed specific guidelines to achieve OBE for the educational institutions in India. The outcome of education is to produce high-quality

\section{G Aruna}

Department of Civil Engineering, CMR Institute of Technology, Hyderabad, India

aarunasree@gmail.com graduates and contributing their knowledge to the welfare of the stakeholders and society. Outcomes are result oriented thinking and are opposite of inputbased education where the emphasis is on the educational process and where we're happy to accept whatever is the result [1]. Any outcomes do not achieve without any specific process. All the process follows the Deming's Quality Cycle such as plan-docheck-act. NBA [2] defines three levels of outcomes such as 1) Program educational objectives (PEOs) 2) Program Outcomes (POs) \& Program-Specific outcomes (PSOs) 3) Course outcomes (COs). PEOs are described that, prepare the graduates to achieve a successful career and professional accomplishments after a few years of graduation and it has been framed by considering local and global issues, vision and mission of the institution. POs and PSOs are defined that, acquired knowledge of graduates at the end of the program in all the areas of graduate attributes and specific core field respectively. Totally 12 POs has been defined by NBA, India [2] by considering the graduate attributes such as engineering knowledge, problem analysis, design/ development of solutions, conduct investigation of complex problems, modern tool usage, the engineer and society, environment and sustainability, ethics, individual and teamwork, communication, project management and finance and life-long learning. PSOs have been framed by the respective program by considering specific attributes in that program. COS are described that, acquired knowledge of students at the end of every course. This has been framed for individual courses in the curriculum. 
Kalbande and Rathod [3] developed the software application for the attainment of POs for reducing the clerical work of faculty members. Izham Zainal Abidin et al. [4] discussed about assessment of course outcomes and developed a computerized Microsoft Excel for an engineering course. Soragon and Mahesh [5], Rudagi and Anita [6], Kulkarni and Barot [7] review the attainment of outcomes through case study. But there is limited papers have been available to assess the outcomes by question wise (micro level analysis). But NBA does not mention any specific method for assessing the attainment of outcomes. Therefore, this paper describes the method to evaluate the attainment of COs, POs and PSOs.

\section{Assessment of Course Outcomes}

All the courses in the undergraduate engineering program have own course outcomes. Each course outcomes will be mapped with POs and PSOs. POs and PSOs will be mapped with PEOs. Figure 1 shows the sequence of framing and assessing of various outcomes. Figure 2 shows the steps for framing the COs [1]. Direct and Indirect method is used to assess the COs. All Internal assessment such as Continuous Internal Evaluation (CIE) test, seminar, assignment, project, and quiz as well as external assessment such as Semester End Examination (SEE) are direct method. Course end survey is the indirect method, which will be collected from the students after completion of each course based on the course outcomes.

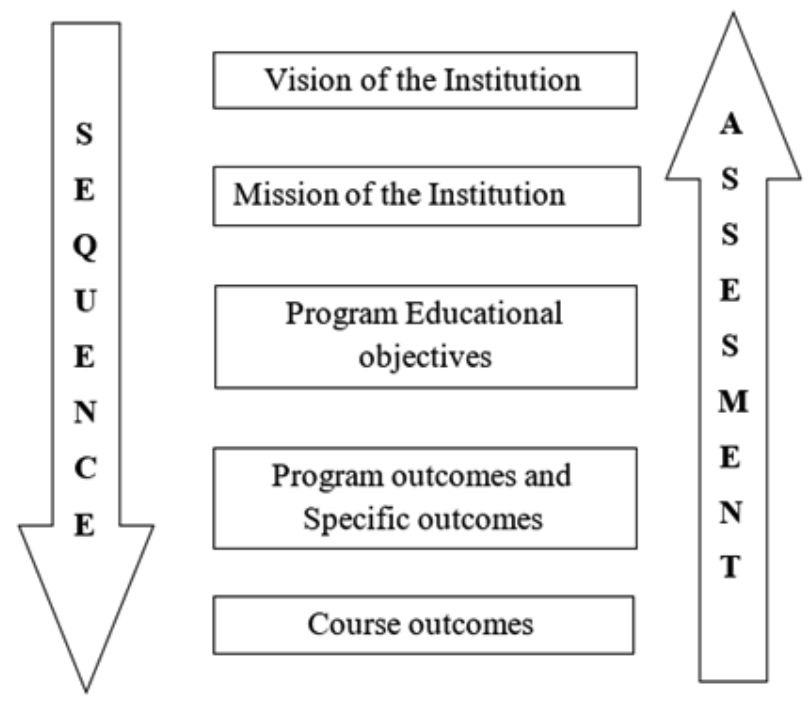

Fig. 1: Sequence of Framing and assessing of outcomes

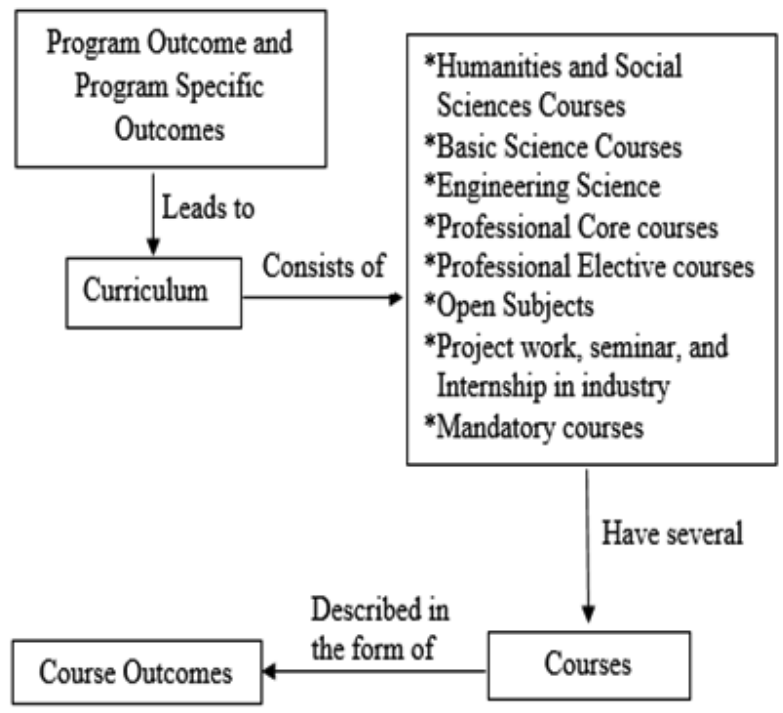

Fig. 2 : Framing of Course Outcomes

Totally five course outcomes have been framed for every course. Questions in the internal evaluation test and SEE are mapped with each course outcomes and presented in Table 1. Percentage of attainment of each course outcome is calculated based on the marks scored by the individual student for the individual question.

Mapping between course outcomes and questions is explained by an example below

Co 1: Analyse indeterminate beams and frames by matrix flexibility method

Question 1: What is element flexibility matrix of the beam element?

Justification: Element flexibility matrix is needed to analyse any indeterminate beams. So this question is strongly mapped with the CO1

Table 1. Mapping of questions with COs

\begin{tabular}{|c|c|c|c|c|c|c|}
\hline \multirow{2}{*}{ 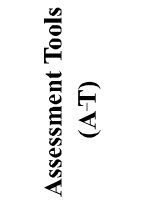 } & \multirow{2}{*}{ 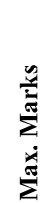 } & \multicolumn{5}{|c|}{ Course Outcomes } \\
\hline & & CO1 & $\mathrm{CO} 2$ & $\mathrm{CO3}$ & $\mathrm{CO} 4$ & $\mathrm{CO5}$ \\
\hline $\begin{array}{l}\text { CIE TEST1 } \\
\text { (CIE1) }\end{array}$ & 50 & $\begin{array}{l}\text { Q1 to } \\
\text { Q6 } \\
\left(2^{*}\right) \\
\& \\
\text { Q11a } \\
\text { or } \\
\text { Q11 } \\
\text { b(16*) }\end{array}$ & $\begin{array}{l}\text { Q7 to } \\
\text { Q9 } \\
\left(2^{*}\right) \\
\& \text { Q10 } \\
\left(16^{*}\right)\end{array}$ & & & \\
\hline
\end{tabular}




\begin{tabular}{|c|c|c|c|c|c|c|}
\hline $\begin{array}{l}\text { CIE TEST2 } \\
\text { (CIE2) }\end{array}$ & 50 & & $\begin{array}{l}\text { Q1 to } \\
\text { Q3 } \\
\left(2^{*}\right) \\
\text { \& Q11 } \\
\left(16^{*}\right) \\
\end{array}$ & $\begin{array}{l}\text { Q4 to } \\
\text { Q9 } \\
\left(2^{*}\right) \\
\text { \& } 111 \\
\left(16^{*}\right) \\
\end{array}$ & & \\
\hline $\begin{array}{l}\text { CIE TEST3 } \\
\text { (CIE3) }\end{array}$ & 50 & & & & $\begin{array}{l}\text { Q1 to } \\
\text { Q5 } \\
\left(2^{*}\right) \\
\text { Q10 } \\
\left(16^{*}\right)\end{array}$ & $\begin{array}{l}\text { Q6 to } \\
\text { Q9 } \\
\left(2^{*}\right) \\
\text { Q11a } \\
\text { or } \\
\text { Q11 b } \\
\left(16^{*}\right)\end{array}$ \\
\hline Assignment & 25 & Q1 & Q2 & Q3 & Q4 & Q5 \\
\hline $\begin{array}{l}\text { Semester end } \\
\text { examination } \\
\text { (SEE) }\end{array}$ & 100 & $\begin{array}{l}\text { Q1, Q2 } \\
\left(2^{*}\right) \& \\
\text { Q11 } \\
\left(16^{*}\right)\end{array}$ & $\begin{array}{l}\text { Q3, Q4 } \\
\left(2^{*}\right) \& \\
\text { Q12 } \\
\left(16^{*}\right)\end{array}$ & $\begin{array}{l}\text { Q5, Q6 } \\
\left(2^{*}\right) \\
\& \\
\text { Q13 } \\
\left(16^{*}\right)\end{array}$ & $\begin{array}{l}\text { Q7, } \\
\text { Q8 } \\
\left(2^{*}\right) \\
\& \\
\text { Q14 } \\
\left(16^{*}\right) \\
\end{array}$ & $\begin{array}{l}\text { Q9, } \\
\text { Q10 } \\
\left(2^{*}\right) \& \\
\text { Q15 } \\
\left(16^{*}\right)\end{array}$ \\
\hline
\end{tabular}

First CIE covers the $\mathrm{CO} 1$ and $\mathrm{CO} 2$ and its marks details of student-1 is depicted in Table 2. Marks scored by student- 1 in CIE, assignment, and SEE are presented in Table3.

Table 2. Details of marks in CIE 1

\begin{tabular}{|c|c|c|c|}
\hline $\begin{array}{c}\text { Question } \\
\text { Number }\end{array}$ & Co Number & $\begin{array}{c}\text { Maximum } \\
\text { Marks }\end{array}$ & $\begin{array}{c}\text { Obtained } \\
\text { Marks }\end{array}$ \\
\hline 1 & $\mathrm{CO} 1$ & 2 & 2 \\
\hline 2 & $\mathrm{CO} 1$ & 2 & 2 \\
\hline 3 & $\mathrm{CO} 1$ & 2 & 2 \\
\hline 4 & $\mathrm{CO} 1$ & 2 & 2 \\
\hline 5 & $\mathrm{CO} 1$ & 2 & 2 \\
\hline 6 & $\mathrm{CO} 1$ & 2 & 2 \\
\hline 7 & $\mathrm{CO} 2$ & 2 & 2 \\
\hline 8 & $\mathrm{CO} 2$ & 2 & 0 \\
\hline 9 & $\mathrm{CO} 2$ & 2 & 0 \\
\hline 10 & $\mathrm{CO} 2$ & 16 & 6 \\
\hline $11 \mathrm{a}$ & $\mathrm{CO} 1$ & 16 & 14 \\
\hline $11 \mathrm{~b}$ & $\mathrm{CO} 1$ & 16 & Choice \\
\hline
\end{tabular}

Table 3. Obtained Marks by student in one course (Direct method)

\begin{tabular}{|c|c|c|c|c|c|c|c|c|c|c|}
\hline \multirow{3}{*}{ A. $T$} & \multicolumn{10}{|c|}{ Course Outcomes } \\
\hline & \multicolumn{2}{|c|}{ CO1 } & \multicolumn{2}{|c|}{$\mathrm{CO} 2$} & \multicolumn{2}{|c|}{$\mathrm{CO3}$} & \multicolumn{2}{|c|}{$\mathrm{CO} 4$} & \multicolumn{2}{|c|}{$\mathrm{CO5}$} \\
\hline & $\mathbf{M}$ & $\mathbf{O}$ & M & $\mathbf{O}$ & $\mathbf{M}$ & $\mathbf{O}$ & M & $\mathbf{O}$ & $\mathbf{M}$ & $\mathbf{O}$ \\
\hline CIE1 & 28 & 26 & 22 & 8 & & & & & & \\
\hline CIE2 & & & 28 & 6 & 22 & 15 & & & & \\
\hline CIE3 & & & & & & & 26 & 20 & 24 & 15 \\
\hline $\mathbf{A}$ & 5 & 2 & 5 & 3 & 5 & 4 & 5 & 3 & 5 & 3 \\
\hline SEE & & & & & 80 ou & of 1 & & & & \\
\hline
\end{tabular}

The performance of the students in the internal evaluation (IE) test and SEE were assessed. The percentage of marks of each COs was calculated by marks scored in the respective $\mathrm{CO}$ out of total marks contribution of that $\mathrm{CO}$

CIE 1 and Assignment gives the contribution to $\mathrm{CO} 1$ as shown in Table 3. Percentage of marks of CO1 of student-1 through internal evaluation is calculated by Percentage of Marks of CO1 $1_{\mathrm{IE}}$

$$
\begin{aligned}
& =\text { Average }\left[\left[\frac{\mathrm{O} . \mathrm{M} \text { of } \mathrm{CO} 1 \text { in CIE } 1}{\mathrm{M} . \mathrm{M} \text { of } \mathrm{CO} 1 \text { in CIE1 }}\right]+\left[\frac{\mathrm{O} . \mathrm{M} \text { of } \mathrm{CO} 1 \text { in } \mathrm{A}}{\mathrm{M} . \mathrm{M} \text { of CO1 in A }}\right]\right] \\
& =\left[\left[\frac{26}{28}\right]+\left[\frac{2}{5}\right]\right] * 100 \\
& \frac{2}{=66 \%}
\end{aligned}
$$

In the SEE, the obtained marks of individual question by the students was not known. So the COs in the SEE was calculated approximately. In this method, the percentage distribution of each question for each $\mathrm{CO}$ was calculated and presented in Table 4. Student-1 scored 80 marks out of 100 in one course of SEE. The percentage of marks of CO1 in SEE is calculated as

Percentage of Marks of $\mathrm{CO} 1_{\mathrm{SEE}}$

$$
\begin{aligned}
& =\left[\frac{\text { Percentage distribution of questions in CO } 1 * O . M}{\text { Maximum Marks }}\right] \\
& =\left[\frac{0.2 * 80}{100}\right] * 100 \\
& =16 \%
\end{aligned}
$$

Table 4. Percentage Distribution of questions

\begin{tabular}{|c|c|c|c|c|c|}
\hline \multirow{2}{*}{ Assessment tools } & \multicolumn{5}{|c|}{ Couse Outcomes } \\
\cline { 2 - 6 } & CO1 & CO2 & CO3 & CO4 & CO5 \\
\hline SEE & $20 \%$ & $20 \%$ & $20 \%$ & $20 \%$ & $20 \%$ \\
\hline
\end{tabular}

Similarly all the COs was assessed. The assesment of COs through SEE is approaximate, so minimum weightage was given to SEE. $80 \%$ and $20 \%$ weightage was given for internal assessment and SEE respectively in the assessment of Cos.

Total Percentage of marks of CO 1 of student- 1 is

$=80 \%$ Percentage of Marks of CO1 IE $+20 \%$ of Percentage of Marks of CO1SEE

$=0.8 * 66+0.2 * 16=56 \%$ 
Class average mark was taken as bench marks. Attainment of COs were calculated by percentage of number of student scored more than or equal to class average marks. Assessment of attainment of course outcomes by direct method is presented in Table 5

Table 5. Assessment of attainment of COs by Direct Method

\begin{tabular}{|c|c|c|c|c|c|c|}
\hline $\begin{array}{l}\stackrel{0}{z} \\
\dot{n}\end{array}$ & 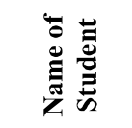 & 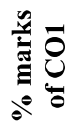 & 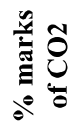 & 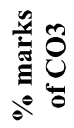 & 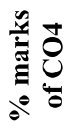 & 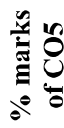 \\
\hline 1 & Student 1 & 56 & 34 & 63 & 58 & 52 \\
\hline 2 & Student 2 & 47 & 53 & 59 & 66 & 66 \\
\hline 3 & Student 3 & 56 & 56 & 56 & 59 & 59 \\
\hline 4 & Student 4 & 52 & 58 & 64 & 59 & 59 \\
\hline \multicolumn{2}{|c|}{$\begin{array}{c}\text { Class Average } \\
\text { Marks }\end{array}$} & 52.75 & 50.25 & 60.5 & 60.5 & 59 \\
\hline \multicolumn{2}{|c|}{$\begin{array}{c}\text { No of Students } \\
\text { more than the } \\
\text { class average } \\
\text { marks }\end{array}$} & 2 & 3 & 2 & 1 & 3 \\
\hline \multicolumn{2}{|c|}{$\begin{array}{l}\text { Attainment by } \\
\text { direct method }\end{array}$} & $50 \%$ & $75 \%$ & $50 \%$ & $25 \%$ & $75 \%$ \\
\hline
\end{tabular}

Course ends survey is the Indirect Assessment tool. Course end survey was carried out at the completion of each course (end of the semester). The course end survey assessed by a range of attributes such as excellent, good, satisfactory, and poor as well as it is framed based on each COs. Attainment of each CO by course end survey of sample course is presented in Table 6.

Table 6. Attainment of each CO by Course End Survey

\begin{tabular}{|l|c|c|c|c|c|c|}
\hline \multicolumn{7}{|c|}{ Course End Survey } \\
\hline \multirow{2}{*}{} & \multirow{7}{*}{ Number of respondent (R) } \\
\hline
\end{tabular}

Weightage was assigned for each attribute and the percentage of attainment was calculated as,
Percentage attainment of $\mathrm{CO} 1$

$$
\begin{aligned}
& =\left[\frac{(W E * R E 1)+(W G * R G 1)+(W S * R S 1)+(W P * R P 1)}{\text { Total strength } * 4}\right] \\
& =\left[\frac{(4 * 20)+(3 * 20)}{40 * 4}\right] * 100 \\
& =87.5 \%
\end{aligned}
$$

where, $\mathrm{WE}=$ Weightage for excellent $=4$,

$\mathrm{WG}=$ Weightage for good $=3$,

WS $=$ Weightage for satisfactory $=2$, and

$\mathrm{WP}=$ Weightage for poor $=1$

RE1,RG1,RS1 and RP1= Number of excellent, good, satisfactory, and poor given by the respondent for the

\begin{tabular}{|c|c|c|c|c|c|c|}
\hline \multirow[t]{2}{*}{ O } & \multirow{2}{*}{ 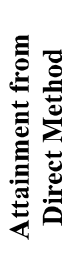 } & \multirow{2}{*}{ 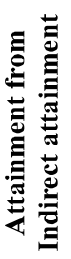 } & 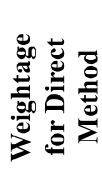 & 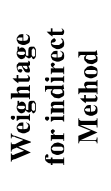 & \multirow[t]{2}{*}{ 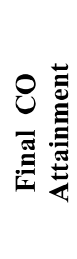 } & \multirow{2}{*}{ 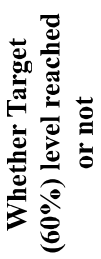 } \\
\hline & & & $80 \%$ & $20 \%$ & & \\
\hline CO1 & $50 \%$ & $88 \%$ & $40 \%$ & $18 \%$ & $58 \%$ & No \\
\hline $\mathrm{CO} 2$ & $75 \%$ & $88 \%$ & $60 \%$ & $18 \%$ & $78 \%$ & Yes \\
\hline $\mathrm{CO3}$ & $50 \%$ & $63 \%$ & $40 \%$ & $13 \%$ & $53 \%$ & No \\
\hline $\mathrm{CO4}$ & $25 \%$ & $94 \%$ & $20 \%$ & $19 \%$ & $39 \%$ & No \\
\hline $\mathrm{CO5}$ & $75 \%$ & $81 \%$ & $60 \%$ & $16 \%$ & $76 \%$ & Yes \\
\hline
\end{tabular}
CO1 respectively.

Table 7. Final CO Attainment

Table 8. Comparison of $\mathrm{CO}$ attainment

\begin{tabular}{|c|c|c|c|c|c|c|}
\hline Batch & $\begin{array}{c}\text { Academic } \\
\text { Year }\end{array}$ & CO1 & CO2 & CO3 & CO4 & CO5 \\
\hline $\begin{array}{c}2013- \\
2017\end{array}$ & $\begin{array}{c}2015- \\
2016\end{array}$ & 58 & 78 & 53 & 39 & 76 \\
\hline $\begin{array}{c}2014- \\
2018\end{array}$ & $\begin{array}{c}2016- \\
2017\end{array}$ & 62 & 76 & 67 & 50 & 80 \\
\hline $\begin{array}{c}2015- \\
2019\end{array}$ & $\begin{array}{c}2017- \\
2018\end{array}$ & 71 & 80 & 74 & 65 & 81 \\
\hline
\end{tabular}

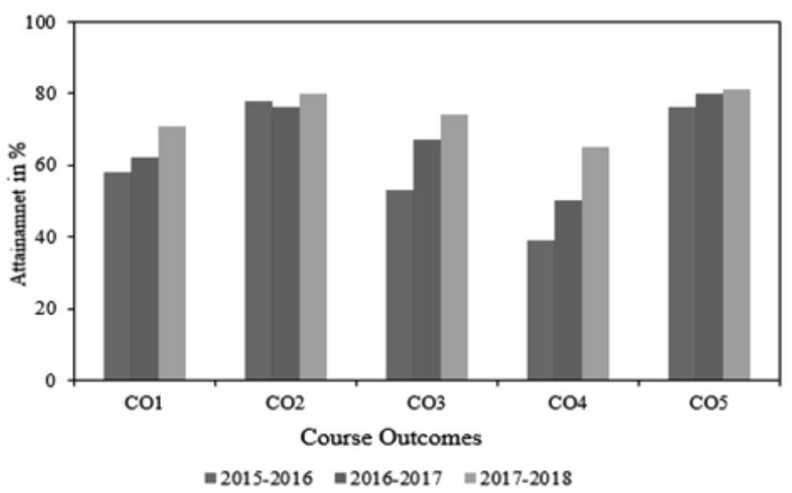

Fig. 3 : Comparison of Course Outcomes 
The final attainment of $\mathrm{CO}$ was calculated by combining the results of the direct and indirect methods and presented in Table 5. Comparsion of CO attainment for the pase three years are presented in Table 8 and shown in Figure 3.

It is observed that, attainment of COs increased gradually. The weightage given for direct and indirect assessment was $80 \%$ and $20 \%$ respectively. Here, target $(60 \%)$ is set, to check whether the CO attained a target level or not. If all COs are attained, increase the target level for the next set of students for the respective course. If one or more COs are not reached the target level, identify the gap and plan to improve the teaching/learning process to attain the target level for the next set of students

\section{Assessment of POS and PSOs}

POs and PSOs are achieved through the course outcomes of individual courses (Direct Method) and other co-curricular, extra-curricular activities, program exit survey, employer's feedback, alumni feedback (indirect method), etc. Attainment of a POs/PSOs depends both on the attainment levels of associated COs and the strength to which it is mapped [1].

Table 9. Attainment of POs and PSOs (Direct Method) of Structural Analysis -1

\begin{tabular}{|c|c|c|c|c|c|c|c|}
\hline \multirow{3}{*}{ 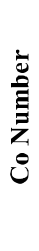 } & \multirow{3}{*}{ 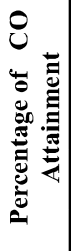 } & \multirow{3}{*}{ 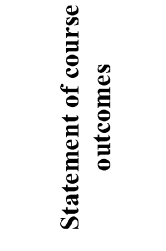 } & \multicolumn{4}{|c|}{ 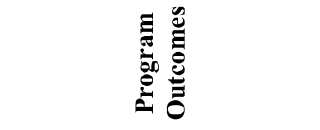 } & \multirow[t]{2}{*}{ 递 } \\
\hline & & & \multicolumn{4}{|c|}{ Mapping strength (MS) } & \\
\hline & & & $\mathbf{a}$ & b & d & $l$ & 1 \\
\hline $\overrightarrow{0}$ & 58 & $\begin{array}{l}\text { Analyse } \\
\text { indeterminate } \\
\text { beams and } \\
\text { frames by } \\
\text { matrix } \\
\text { flexibility } \\
\text { method }\end{array}$ & 3 & 3 & 2 & 2 & 3 \\
\hline$\underset{\circlearrowright}{0}$ & 78 & $\begin{array}{l}\text { Analyse } \\
\text { indeterminate } \\
\text { beams and } \\
\text { frames by } \\
\text { matrix } \\
\text { stiffness } \\
\text { method. }\end{array}$ & 3 & 3 & 2 & 2 & 3 \\
\hline$\hat{o}$ & 53 & $\begin{array}{l}\text { Develop } \\
\text { finite element } \\
\text { equation for } \\
\text { various } \\
\text { elements }\end{array}$ & 3 & 2 & & 2 & 3 \\
\hline ¿ & 39 & $\begin{array}{l}\text { Analyse } \\
\text { indeterminate } \\
\text { beams and } \\
\text { frames by } \\
\text { plastic theory. }\end{array}$ & 3 & 3 & 2 & 2 & 3 \\
\hline
\end{tabular}

\begin{tabular}{|c|c|l|c|c|c|c|c|}
\hline \multirow{2}{*}{76} & $\begin{array}{l}\text { Analyse the } \\
\text { space truss, } \\
\text { beams in } \\
\text { curved planes } \\
\text { and cable } \\
\text { structures. }\end{array}$ & 3 & 3 & 2 & 2 & 3 \\
\hline \\
$\begin{array}{l}\text { POs and PSOs } \\
\text { Attainment }\end{array}$ & 60.8 & 56.8 & 41.8 & 40.5 & 60.8 \\
\hline
\end{tabular}

Correlation levels 1, 2 or 3 are defined as 1: Slight (Low); 2: Moderate (Medium); 3: Substantial (High)

Mapping between COs and POs, \& PSOs is presented in Table 9. Table 10 shows the justification for mapping of $\mathrm{CO} 1$ with various POs and PSOs.

Table 10. Justification for mapping between CO1 with POs and PSOs

\begin{tabular}{|c|c|c|}
\hline \multirow{5}{*}{$\begin{array}{l}0 \\
0 \\
0\end{array}$} & $\varrho^{\pi}$ & $\begin{array}{l}\text { Student has to apply engineering knowledge to } \\
\text { analyse the indeterminate beams and frames. So } \\
\text { CO1 substantially map with POa }\end{array}$ \\
\hline & & $\begin{array}{l}\text { Student has to } \\
* \text { Identify the end condition and whether the } \\
\text { frame is subjected to sway or without sway? } \\
\text { *Formulate the element flexibility matrix and } \\
\text { analyse indeterminate beams and frames. So CO1 } \\
\text { substantially map with POb }\end{array}$ \\
\hline & ?ִ & $\begin{array}{l}\text { Student has to provide conclusion to some extent } \\
\text { based on the analysis of results } \\
\text { So CO1 moderately map with POd }\end{array}$ \\
\hline & $\widetilde{\varrho}$ & $\begin{array}{l}\text { Student has an ability to enhance life } \\
\text { learning skills to some extent.So CO1 moderately } \\
\text { map with } \mathrm{PO} l\end{array}$ \\
\hline & $\bar{\emptyset}$ & $\begin{array}{l}\text { Student has to analyse all structural elements. So } \\
\text { CO1 substantially map with PSO1 }\end{array}$ \\
\hline
\end{tabular}

where,

(Poa) Engineering knowledge: Apply the knowledge of mathematics, science, engineering fundamentals, and an engineering specialization to the solution of complex engineering

(Pob) Problem analysis: Identify, formulate, review research literature, and analyse complex engineering problems reaching substantiated conclusions using first principles of mathematics, natural sciences, and engineering sciences.

(Pod) Conduct investigations of complex problems: Use research-based knowledge and research methods including design of experiments, analysis and interpretation of data, and synthesis of the information to provide valid conclusions problems 
(Pol ) Life-long learning: Recognize the need for, and have the preparation and ability to engage in independent and life-long learning in the broadest context of technological change

(PSO1) Plan, analyse, and design, all kinds of Civil Engineering Projects

Totally 12 POs and 2 PSOs have been framed and assessed. The POs and PSOs were mapped with individual course outcomes based on their correlation between them like strong (3), medium (2) and, low (1) and it is presented in Table 9 for the course Structural Analysis 1.

Percentage of attainment of POd calculated as,

$$
\begin{aligned}
& =\left\{\begin{array}{c}
\left(P C O 1 \frac{M S 1-a}{\text { Max.MS }}\right)+\left(P C O 2 \frac{M S 1-a}{\text { Max.MS }}\right)+\left(P \operatorname{CO} 3 \frac{M S 1-a}{\text { Max.MS }}\right) \\
+\left(P C O 4 \frac{M S 1-a}{\text { Max.MS }}\right)+\left(P \operatorname{CO} 5 \frac{\text { MS } 1-a}{\text { Max.MS }}\right)
\end{array}\right\} \\
& =\left\{\begin{array}{c}
\left(58 \frac{3}{3}\right)+\left(78 \frac{3}{3}\right)+\left(53 \frac{3}{3}\right) \\
+\left(39 \frac{3}{3}\right)+\left(76 \frac{3}{3}\right)
\end{array}\right\} \\
& =60.8 \%
\end{aligned}
$$

where, PCO1, PCO2, PCO3, PCO4, PCO5 = Percentage of attainment of $\mathrm{CO} 1, \mathrm{CO} 2, \mathrm{CO} 3, \mathrm{CO} 4$, and $\mathrm{CO} 5$ respectively.

MS1-a = Mapping strength between CO1 and program outcome 'a', Max.MS= Maximum mapping strength, which is 3

Similarly, the attainment of POs and PSOs for each course was assessed and consolidate at the end of the program. Furthermore, an indirect assessment was included in the attainment of POs and PSOs, such as students (exit survey), employer's survey, alumni's survey, etc. These surveys were taken at the end of the duration of the program. For the final assessment of POs and PSOs, $70 \%$ and $30 \%$ weightage was given for direct and indirect assessment respectively and it depicted in Table 11. Distribution of weightage between direct and indirect assessment varies depends upon the number of surveys taken in the indirect method.

Target was set as $60 \%$ for 2013-2017 batch students. The attainment of POs and PSOs was checked against target level. The results of the attainment are presented in Table 11. The results for

\begin{tabular}{|c|c|c|c|c|c|c|}
\hline \multirow[b]{2}{*}{ 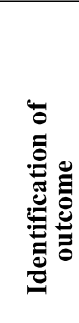 } & \multicolumn{4}{|c|}{ Assessment through } & \multirow[b]{2}{*}{ 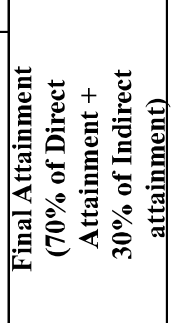 } & \multirow[b]{2}{*}{ 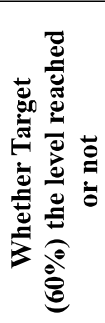 } \\
\hline & 己ُّ & 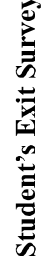 & 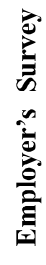 & 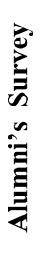 & & \\
\hline $\mathrm{POa}$ & 61 & 81 & 75 & 75 & 65.8 & yes \\
\hline $\mathrm{POb}$ & 56 & 82 & 81 & 77 & 63.2 & yes \\
\hline POc & 55 & 85 & 80 & 72 & 62.2 & yes \\
\hline POd & 53 & 86 & 80 & 77 & 61.4 & yes \\
\hline POe & 55 & 80 & 81 & 78 & 62.4 & yes \\
\hline POf & 53 & 82 & 81 & 81 & 61.5 & yes \\
\hline $\mathrm{POg}$ & 49 & 92 & 88 & 77 & 60 & yes \\
\hline $\mathrm{POj}$ & 53 & 88 & 82 & 79 & 62 & yes \\
\hline POi & 59 & 87 & 75 & 76 & 65.1 & yes \\
\hline $\mathrm{POj}$ & 55 & 84 & 85 & 80 & 63.4 & yes \\
\hline POk & 48 & 92 & 88 & 88 & 60.4 & yes \\
\hline $\mathrm{POl}$ & 55 & 85 & 88 & 83 & 64.1 & yes \\
\hline PSO1 & 52 & 90 & 85 & 82 & 62.1 & yes \\
\hline PSO2 & 51 & 93 & 88 & 85 & 62.3 & yes \\
\hline
\end{tabular}

Table 11. Final Attainment of POs and PSOs (2013-2017)

the past three batch student are presented in Table 12 and shown in Figure 4. Results of 2013-2017, shown that all the POs and PSOs attain the target level. Hence, the target level was increased as $65 \%$ for the next batch (2014-2018) of students. It was observed that POa and POi reached the target level.Remaing outcomes did not reach the target level. So the gap was identified and action taken was implemented for the next batch (2015-2019) students. Improving or introducing the new teaching-learning process, improve the curriculum, etc., are the some of the action taken. So the 2015-2019 batch, reached the target level $65 \%$. Hence target level can be increased for next batch of students.

Target was set as $60 \%$ for 2013-2017 batch students. The attainment of POs and PSOs was checked against target level. The results of the attainment are presented in Table 11. The results for the past three batch student are presented in Table 12 and shown in Figure 4. Results of 2013-2017, shown that all the POs and PSOs attain the target level. Hence, the target level was increased as $65 \%$ for the next batch (2014-2018) of students. It was observed that POa and POi reached the target level.Remaing outcomes did not reach the target level. So the gap was identified and action taken was implemented for the next batch (2015-2019) students. Improving or introducing the new teaching-learning process, improve the curriculum, etc., are the some of the 
Table 12. Final Attainment of POs and PSOs

\begin{tabular}{|c|c|c|c|}
\hline \multirow{2}{*}{$\begin{array}{c}\text { POs \& } \\
\text { PSOs / }\end{array}$} & 2013-2017 & 2014-2018 & $\mathbf{2 0 1 5 - 2 0 1 9}$ \\
\cline { 2 - 4 } & & 66 & 68 \\
\hline $\mathrm{a}$ & 66 & 64 & 65 \\
\hline $\mathrm{b}$ & 63 & 63 & 67 \\
\hline $\mathrm{c}$ & 62 & 62 & 66 \\
\hline $\mathrm{d}$ & 61 & 63 & 65 \\
\hline $\mathrm{e}$ & 62 & 63 & 66 \\
\hline $\mathrm{f}$ & 62 & 61 & 65 \\
\hline $\mathrm{g}$ & 60 & 63 & 66 \\
\hline $\mathrm{h}$ & 62 & 66 & 67 \\
\hline $\mathrm{i}$ & 65 & 64 & 65 \\
\hline $\mathrm{j}$ & 63 & 61 & 66 \\
\hline $\mathrm{k}$ & 60 & 65 & 65 \\
\hline $\mathrm{l}$ & 64 & 63 & 68 \\
\hline $\mathrm{l}$ & 62 & 63 & 67 \\
\hline 2 & 62 & & \\
\hline
\end{tabular}

action taken. So the 2015-2019 batch, reached the target level $65 \%$. Hence target level can be increased for next batch of students.

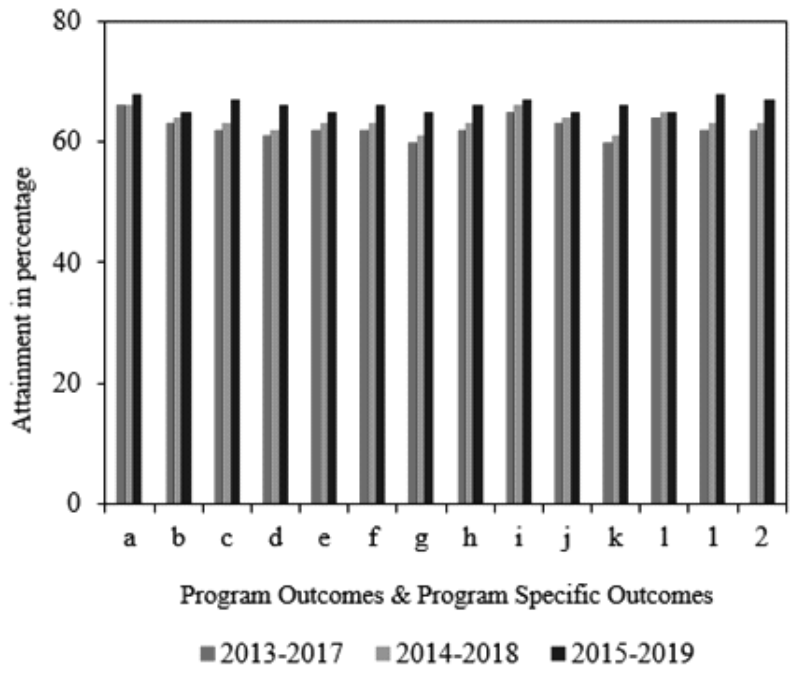

Fig. 4 : Comparison of Program \& Program Specific Outcomes

\section{Conclusion}

A method to find the attainment of COs, POs, and PSOs has been described. It can be implemented using Microsoft Excel software. A direct and indirect method for assessment has been explained.
Assessment of outcomes facilitates the continuous quality improvement of engineering educations. This procedure will be helpful for those who new for outcome based education.

\section{Acknowledgment}

The supports given to this work by the Sona College of Technology, India are greatly acknowledged.

\section{References}

[1] Government of Karnataka (2015), Preparation for NBA accreditation, Department of Technical Education www.dte.kar.nic.in

[2] National Board of accreditation (2016), SelfAssessment report format undergraduate engineering program, India. www.nbaind.org[

[3] Kalbande, D.R, and Rathod, S.S (2016) Software development for Course and Program Outcome attainment, Journal of Engineering Education $\mathrm{Tr}$ a n s o r m a t i o n s, D O I : $10.16920 /$ jeet/2016/v0i0/85634

[4]Izham Zainal Abidin, Adzly Anuar and Norshah Hafeez Shuaib (2009), Assessing the attainment of course outcomes (co) for an engineering course, International Conference of Teaching and Learning, INTI University College, Malaysia

[5]Bhimasen Soragaon, and Mahesh, K .S (2016), Measuring attainment of course outcomes and program outcomes- A simplified approach as per self-assessment report-june 2015, IOSR Journal Research \& Method in Education.Vol(6), 13-18.

[6] Rudagi, M, and Anita Patil (2019), A case study on Assesmnet and attainment of course outcomes, program outcomes and program specific outcomes for Tier-II institutions, IOSR Journal Research \& Method in Education. Vol(9), 60-66.

[7] Kulkarani, G and Barot, R [2019], Attainment of course outcomes and program outcomes: A case study in an Engineering Course, International Journa of Science Technology \& Engineering, Vol (5), 40-45. 